\title{
Stream and Ground-Water Monitoring Program, Lake Tahoe Basin, Nevada and California
}

Lake Tahoe has long been admired for its alpine setting and the clarity of its water. During the last half-century, however, human activity in the lake basin has increased while the lake has been losing water clarity at a rate of about 1 foot (ft) per year. The Tahoe Regional Planning Agency (TRPA), the U.S. Geological Survey (USGS), and the Tahoe Research Group of the University of California, Davis (TRG) are monitoring loads of sediment and important nutrients flowing into the lake from the streams and ground-water aquifers in the basin. This fact sheet provides an overview of that monitoring program and summarizes some of the results regarding loads of sediment and nutrients to the lake.

\section{Basin Geography}

The basin is surrounded by mountain peaks of the Sierra Nevada to the west and the Carson Range to the east (fig. 1). The lake is renowned for its deep, clear water which, on sunny days, appears to be cobalt-blue. The Lake Tahoe Basin was formed by downward block faulting during the uplift of the Sierra Nevada 2-3 million years ago, which resulted in dramatic topographic relief. Mountain peaks, snow capped nearly yearround, rise to altitudes above 10,000 ft above sea level. Lake Tahoe, 1,646 $\mathrm{ft}$ deep, is the second deepest lake in the United States and tenth deepest in the world. It has an average lake-surface altitude of about 6,225 ft.

The Lake Tahoe Basin is 506 square miles $\left(\mathrm{mi}^{2}\right)$. The surface area of the Lake is $192 \mathrm{mi}^{2}$, and the watershed area is $314 \mathrm{mi}^{2}$. Most of the land in the basin is mountainous, limiting development mainly to relatively flatlying areas along tributary streams, such as the southern part of the basin within the Upper Truckee River and Trout Creek Basins. About 78 percent of the basin is at altitudes from about $6,500 \mathrm{ft}$ to greater than $10,000 \mathrm{ft}$. This altitude range, combined with other factors such as prevailing storm systems from the Pacific Ocean, causes an unequal distribution of precipitation throughout the basin. More than 80 inches per year (in/yr) of precipitation, mostly as snow, falls on the western side of the basin, whereas about $30 \mathrm{in} / \mathrm{yr}$ falls on the eastern side.

Since 1874, the outflow of Lake Tahoe into the Truckee River has been regulated by a dam at Tahoe City, Calif. The current dam was built by the Bureau of Reclamation in 1913 to provide irrigation water for the
Newlands Project in the Fallon, Nev., area. The upper $6 \mathrm{ft}$ of the lake forms the largest storage reservoir in the Truckee River Basin, with an effective capacity of 745,000 acre-feet (acre-ft), about 0.6 percent of the estimated 122 million acre-ft in the lake. The dam is operated by the U.S. District Court Water Master under a complex set of legal agreements and operating rules to maintain levels between a maximum altitude of $6,229.1 \mathrm{ft}$ and the altitude of the natural $\operatorname{rim}(6,223 \mathrm{ft})$. During droughts the lake level can fall below the rim, and during wet years the lake level can rise higher than the legal maximum. Since 1987, the lake levels have fluctuated from $6,220.26 \mathrm{ft}$ (about $3 \mathrm{ft}$ below the rim), during a prolonged drought in 1992, to $6,229.39 \mathrm{ft}$ (about $0.2 \mathrm{ft}$ above the legal maximum), during the flood of January 1997.

The Lake Tahoe Basin is divided by the NevadaCalifornia State line, with about one-third of the basin in Nevada and two-thirds in California. The location of the basin, about 150 miles (mi) from the San Francisco Bay area and $90 \mathrm{mi}$ from the Sacramento Valley, makes a wide variety of recreational opportunities available to a population of about 8 million. Major recreational activities within the basin include casino gaming in Nevada, alpine and cross-country skiing, golfing, water sports, hiking, fishing, camping, and bicycling.

\section{History of Environmental Regulation}

Until its "discovery" in 1844 by General John C. Fremont, the basin was occupied by the Washoe Tribe who had hunted and fished there for centuries. Upon discovery of gold in the South Fork of the American River in 1848, thousands of west-bound gold seekers passed near the basin on their way to the gold fields. "White-man's" civilization first made its mark in the Lake Tahoe Basin with the 1858 discovery of the Comstock Lode, just $15 \mathrm{mi}$ to the east in Virginia City, Nev. From 1858 until about 30 years later, logging in the basin supplied large timbers to shore up the underground workings of the Comstock mines. The logging was so extensive that almost all of the native forest was cut. In 1864, Tahoe City was founded as a resort community for Virginia City, the first recognition of the basin's potential as a destination resort area. 
Public appreciation of the Tahoe Basin grew, and during the 1912, 1913, and 1918 congressional sessions, unsuccessful efforts were made to designate the basin as a national park. During the first half of this century, development around the lake consisted of a few vacation homes. The postWorld War II population and building boom, followed by construction of gambling casinos in the Nevada part of the basin during the mid-1950's, and completion of the interstate highway links for the 1960 Squaw Valley Olympics, resulted in a dramatic increase in development within the basin. From 1960 to 1980, the permanent resident population increased from about 10,000 to greater than 50,000 , and the summer population grew from about 10,000 to about 90,000 .

Increased development included urbanization of wetland areas that had formerly served as zones for retention of sediments and nutrients (nitrogen, phosphorus, and iron); development on steep mountain sides with consequent sediment erosion; discharge of septic and sewage systems within the basin; and increased airborne nutrients from automobile emissions and wood-burning stoves.

By the 1950's, evidence was mounting that the clarity of the lake was decreasing. Concerns about the effects of sewage effluent and septicsystem leakage on stream and lake quality led to formation of the Lake Tahoe Area Council (LTAC) which, in a historic decision, acted to develop a basin-wide sewage-collection system by which the effluent would be exported from the basin, primarily to other areas in Douglas County, Nev., and in Alpine County, Calif. During this time, researchers of TRG documented increases in algal growth and decreases in lake clarity. It was suspected that development was increasing transport of nutrients to the lake, thus stimulating growth of algae.

In 1969, at the joint request of the States of California and Nevada, TRPA was chartered by Federal law under an Interstate Compact. TRPA

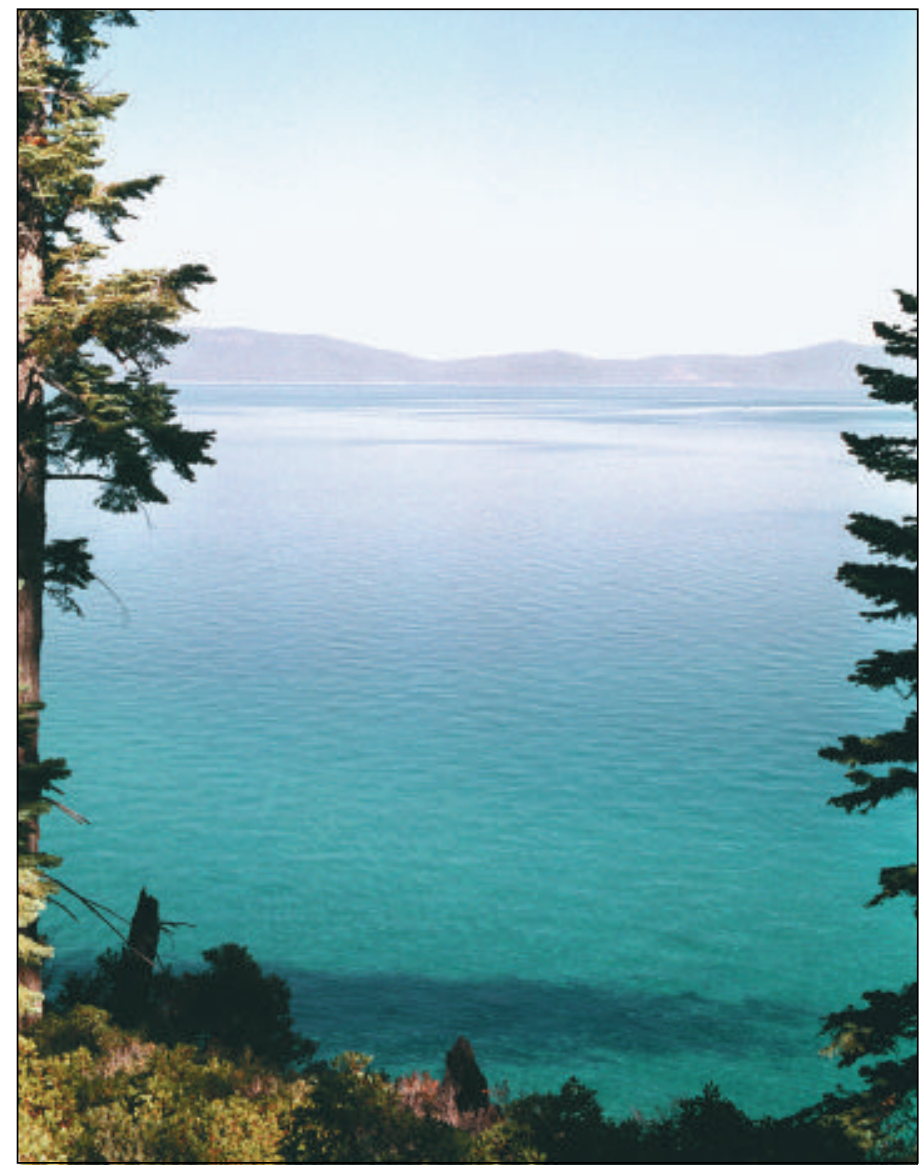

Lake Tahoe, September 1996; eastward view from Rubicon Point, California. Photograph by Timothy G. Rowe, U.S. Geological Survey.

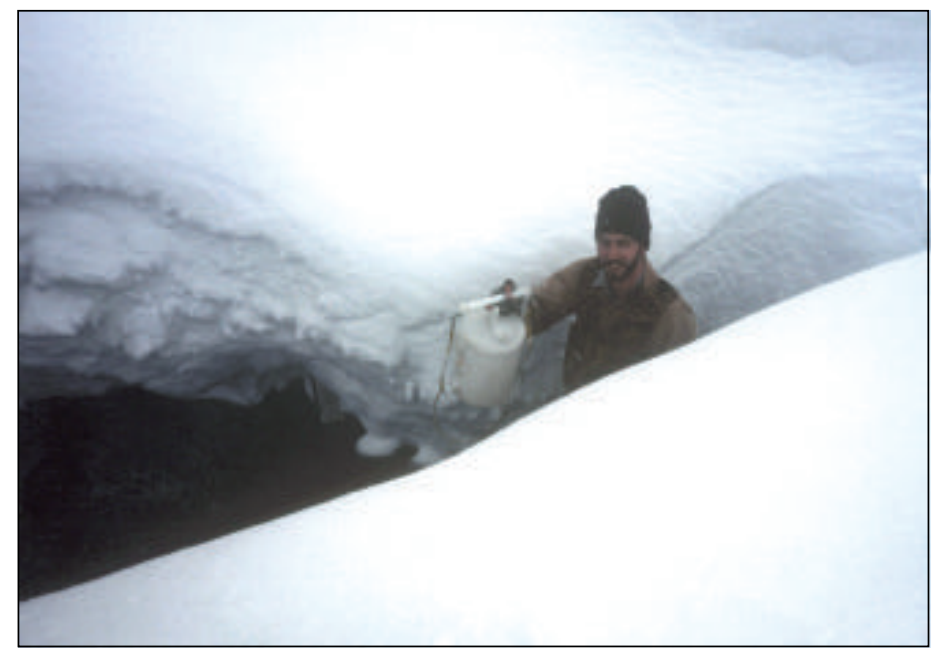

Sampling water quality at Incline Creek, January 1993. Photograph by Rita Whitney, U.S. Geological Survey.

was formed as a bi-state agency to better manage and regulate land use and development to protect the lake and the natural resources of the basin. The first two decades of TRPA's management focused on development and application of land-use regulations. In the early 1990's, the agency shifted focus from regulation to science-based environmental management and decision making.

\section{LTIMP Cooperative Monitoring Program}

In 1978, the Lake Tahoe Interagency Monitoring Program (LTIMP) was formed. This group included collaborative monitoring and research efforts among TRPA, USGS, TRG, U.S. Forest Service, California State Water Resources Control Board (CSWRCB), Lahontan Regional Water Quality Control Board, California Department of Water Resources (DWR), California Department of Transportation, California Air Resources Board, California Department of Fish and Game, Nevada Department of Environmental Protection, and U.S. Environmental Protection Agency (EPA). The combined resources of LTIMP have contributed significantly to the body of literature and hydrological and limnological data available for the Lake Tahoe Basin.

Although early concerns focused on suspended-sediment and nutrient transport to the lake by streams, potential nutrient contribution by ground water became recognized in the late 1980's. Suspected sources included abandoned septic systems, golf courses, organic-rich stream deposits, and contaminated surface-water infiltration into ground water.

In 1982, TRPA adopted Resolution No. 82-11, which includes environmental thresholds for the Lake Tahoe Basin. Among those thresholds is "Water Quality 4," which establishes standards for total nitrogen, soluble inorganic nitrogen, total phosphorus, soluble phosphorus, total iron, and suspended sediment in tributary streams.

TRPA also adopted "Water Quality 6," a threshold that establishes standards for total nitrogen, total phosphorus, total iron, turbidity, and grease and oil in surface discharge to ground water.

These thresholds provide the basis for the current program for stream and ground-water monitoring operated cooperatively by TRPA, USGS, and TRG. Since 1988, funding for this program has been shared equally by TRPA and USGS, with additional support and services provided by TRG.

The California part of Lake Tahoe is designated by EPA as an Outstanding Natural Resource Water, which provides that no further degradation of Lake Tahoe can be allowed. All reasonable, cost-effective, best-management practices for nonpoint source control are required. Under 


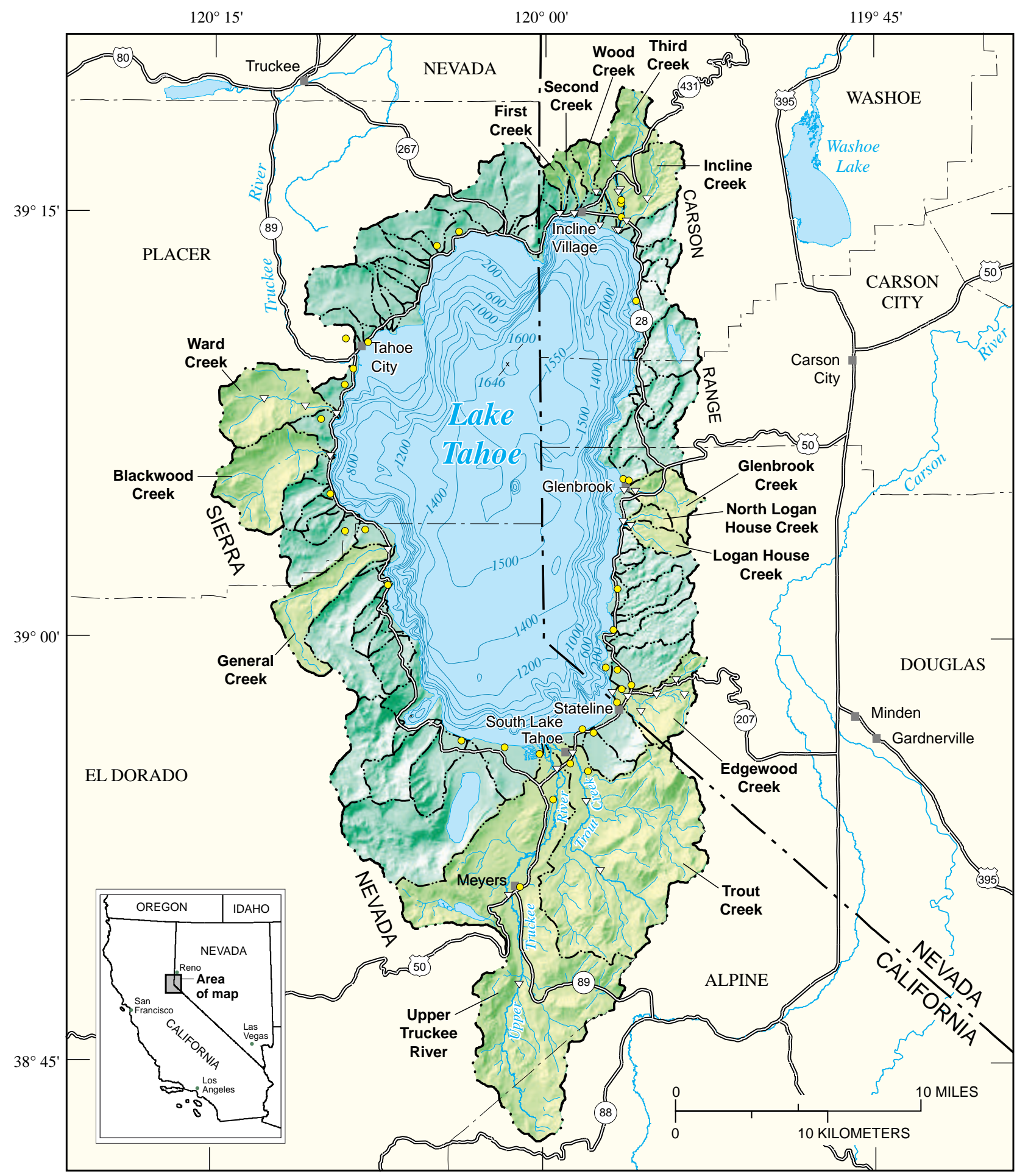

Base from U.S. Geological Survey digital data, 1:24,000 and 1:100,000, 1969-85. Universal Transverse Mercator projection, Zone 11

Bathymetric contours from Rush, 1973. Compiled from EXPLANATION

\begin{tabular}{lrl}
\hline $\begin{array}{l}\text { Selected hydrologic basin used } \\
\text { in this study }\end{array}$ & $-1200-\begin{array}{l}\text { Bathymetric contour, in feet below highest } \\
\text { legal lake-surface altitude }(6,229.1 \text { feet above }\end{array}$ \\
$-\cdots-$ Boundary of Lake Tahoe Basin & $\nabla . S$. Bureau of Reclamation datum of 1929) \\
$-\cdots-\quad$ Boundary of subbasin & $\circ \quad \begin{array}{l}\text { Surface-water site } \\
\text { Ground-water site }\end{array}$
\end{tabular}

Figure 1. Geographic setting, hydrologic basins, bathymetry, and surface-water and ground-water monitoring sites in the Lake Tahoe Basin. 


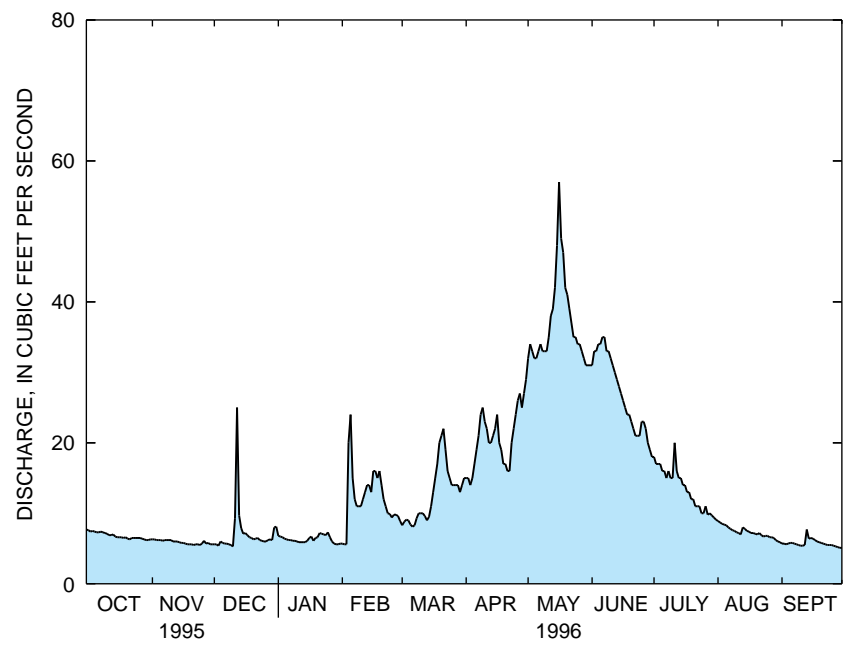

Figure 2. Daily mean discharge for Incline Creek during 1996 water year, representative of streams in the Lake Tahoe Basin.

Nevada Pollution Control Regulations, the Nevada part of Lake Tahoe has a designated beneficial use as a water of extraordinary ecological and/or aesthetic value, which is also a nondegradation standard (Adelle Basham, Nevada Department of Environmental Protection, oral commun., 1997). Although no specific monitoring program has been implemented within the basin to meet all the requirements of these policies, regulatory agencies rely upon LTIMP data in implementation of their programs.

\section{Stream Monitoring Network}

In 1979, the LTIMP stream-sampling network began as a cooperative effort of the CSWRCB, DWR, USGS, and TRG. The objectives of this network are to acquire and disseminate the water-quality information necessary to support science-based environmental planning and decision making in the basin. Seven major tributary streams were monitored for streamflow and suspended-sediment and nutrient contribution to Lake Tahoe. By 1987, decreases in funding had reduced the network to four streams in California: General, Blackwood, and Ward Creeks, and Upper Truckee River.

In 1987, TRPA and USGS provided funding to expand the program by adding four Nevada tributaries. By 1993, the LTIMP network had expanded to 32 sites in 14 basins (fig. 1). Of the 32 sites, 20 have recording streamflow gages. The 14 basins total $157 \mathrm{mi}^{2}$, or about half of the entire basin tributary to Lake Tahoe. The largest basin monitored is the Upper Truckee River Basin $\left(56.5 \mathrm{mi}^{2}, 18\right.$ percent of the total drainage to the lake); the smallest is the First Creek Basin $\left(1.08 \mathrm{mi}^{2}\right)$.

Routine and storm-based monitoring is done to provide data for comparisons between spring runoff, storm-generated runoff, and baseflow, and for estimating suspended-sediment and nutrient transport. Comparisons can be made among the 14 monitored basins. Monitoring stations at the mouths of the basins measure loads to the lake and provide a basis for comparisons of the effects of the differing geology, soils, and land uses on those loads. Eight of the basins also have internal sampling stations to allow for comparisons of the effects of upstream and downstream land uses.

The greatest transport of sediment and some associated nutrients occurs during high flows caused by storms and snowmelt. To quantify transport during such events, individual samples must be collected as the streamflows rise, peak, and recede. A timely and steady field presence in the basin during storms is required to accomplish this. During runoff monitoring, USGS field crews frequently collect hydrologic data late into the night and on weekends and holidays to meet the program objectives.
Tributary monitoring includes field measurement of streamflows, temperature, $\mathrm{pH}$, dissolved oxygen, and specific conductance; and laboratory measurement of major nutrients (dissolved nitrate and nitrite, dissolved ammonia, total ammonia and organic nitrogen, dissolved orthophosphorus, total phosphorus, and total iron) and suspended sediment. These measurements are necessary to determine whether the environmental thresholds for the basin are being exceeded and to provide long-term data that can be used to determine suspended-sediment and nutrient loads to the lake.

Depth-integrating and equal-width-increment sampling techniques are used for suspended-sediment and nutrient sampling. Suspended-sediment analyses are made by the USGS California sediment laboratory in Salinas, Calif. Nutrient analyses are done at TRG laboratories in Tahoe City and Davis, Calif. The streamflow gages are operated by USGS personnel from the Carson City, Nev., and Carnelian Bay, Calif., field offices. LTIMP data are entered in national USGS data bases and published every year in USGS California and Nevada Water Data Reports.

\section{Ground-Water Monitoring Network}

In 1990, USGS and TRPA established a ground-water monitoring network with 32 sampling sites (fig. 1) to provide a long-term data base on ground water. Previous ground-water studies found concentrations of nitrogen, phosphorus, and iron to be greater in ground water than in the lake. These studies indicated the need to better describe ground-water quality and rates of ground-water flow into the lake.

Field measurements of water from wells include temperature, $\mathrm{pH}$, dissolved oxygen, specific conductance, and water level. Laboratory measurements of dissolved nutrients, including iron, are made. Groundwater samples are obtained by pumping long enough to remove stagnant well water before sampling.

\section{Monitoring Results}

The monitoring provides scientific data on stream discharge and quality and ground-water levels, quality, and flow paths. Selected results are described below.

The hydrograph of daily mean discharge for Incline Creek (fig. 2) for 1996 shows a seasonal pattern that is typical of streams in the Lake Tahoe Basin. Most runoff is during the April through June snowmelt period. Sharp peaks represent fall rains, rain-on-snow storms, and summer thunder storms.

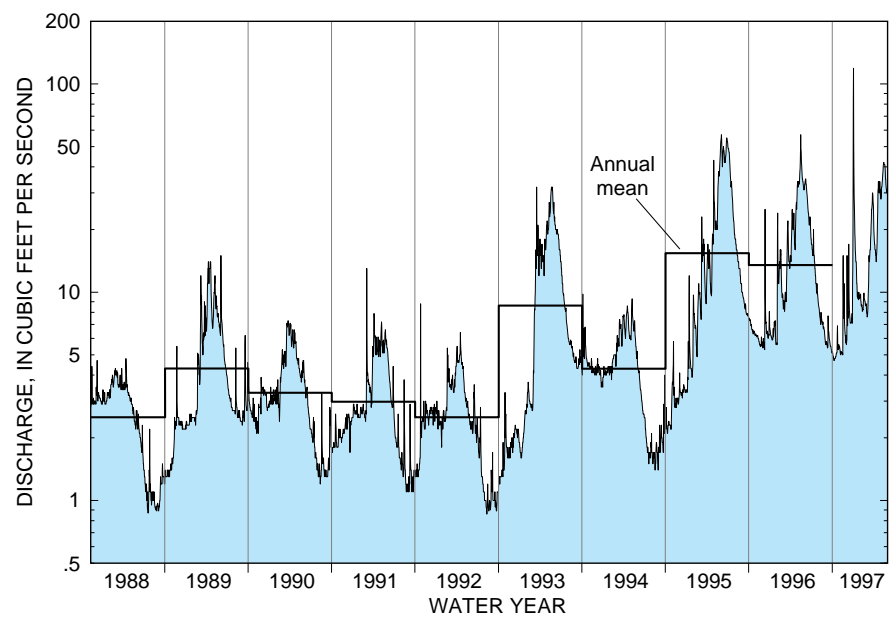

Figure 3. Mean daily discharge for Incline Creek, 1988-97 water years, representing years of drought and above-normal runoff. 


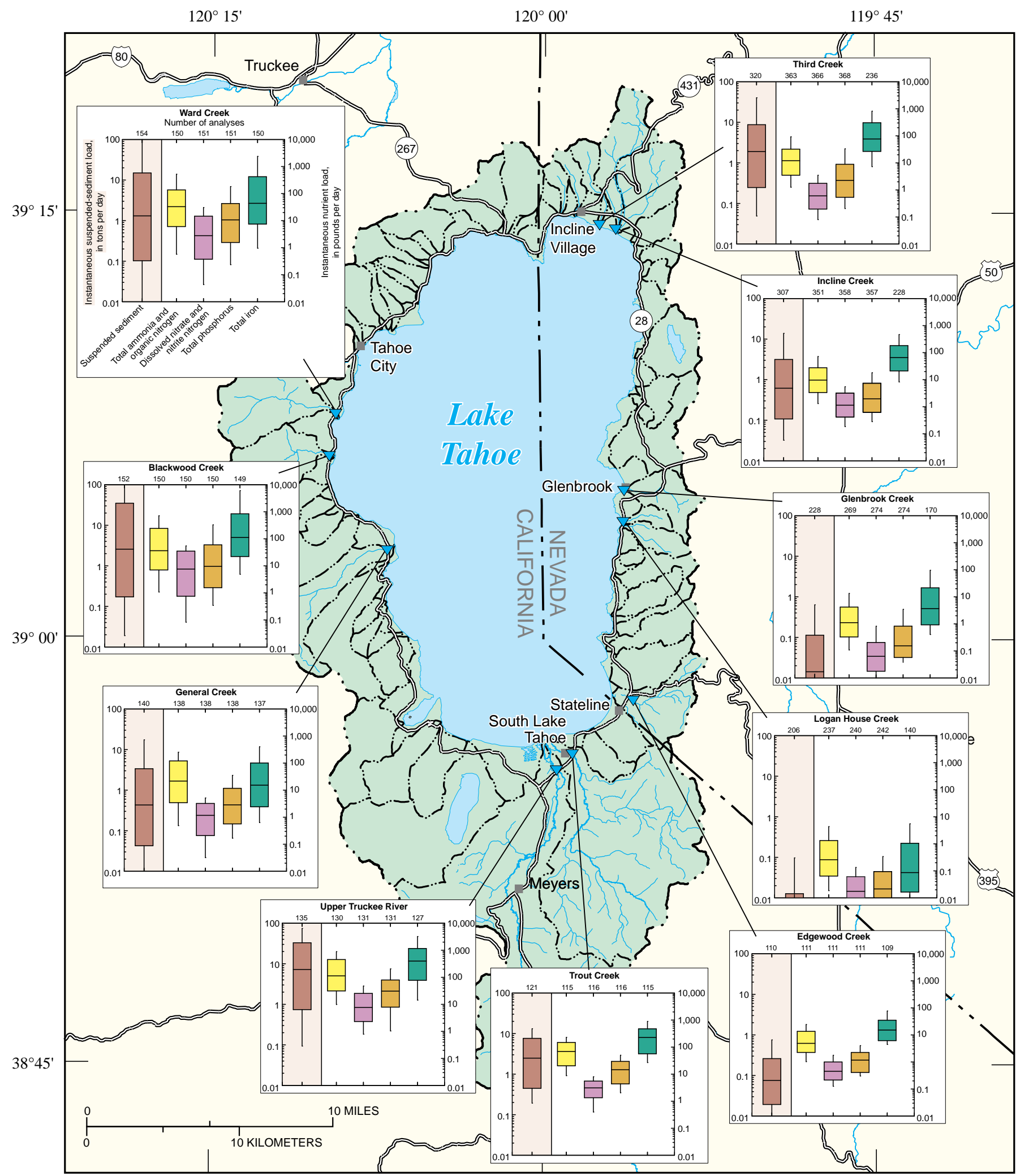

Base from U.S. Geological Survey digital data, 1:24,000 and 1:100,000, 1969-85 Universal Transverse Mercator projection, Zone 11

EXPLANATION
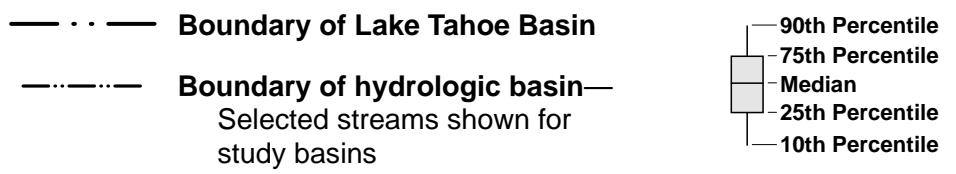

Figure 4. Instantaneous suspended-sediment and nutrient loads depicted by box plots for selected surface-water monitoring sites in the Lake Tahoe Basin. 


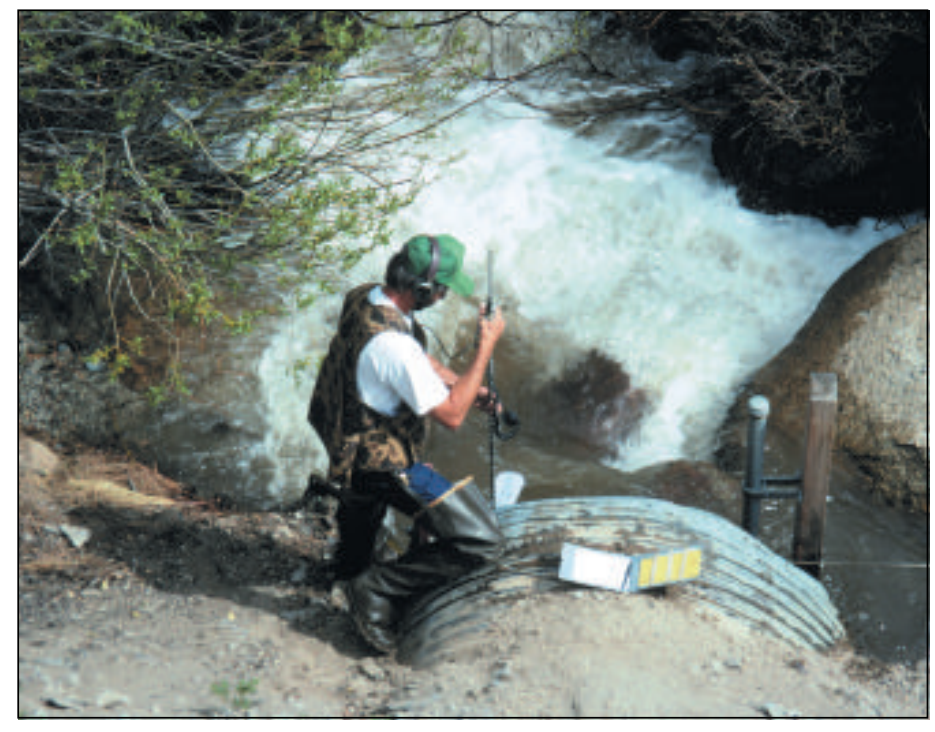

Measuring streamflow at Third Creek, May 1993. Photograph by Timothy G. Rowe, U.S. Geological Survey.

The longer term hydrograph (fig. 3) for Incline Creek for the 9-year period of record clearly shows the effects of drought (water years 1988-92 and 1994) as compared to years in which runoff was above normal (1993, 1995, and 1996). The mean daily discharge for the 9 years is $6.38 \mathrm{ft}^{3} / \mathrm{s}$. The highest mean daily discharge $\left(15.4 \mathrm{ft}^{3} / \mathrm{s}\right)$ was in 1995 and the lowest $\left(2.51 \mathrm{ft}^{3} / \mathrm{s}\right)$ in 1992 . The average annual runoff for the period of record is 5,160 acre-ft. Among the 14 basins monitored, the Upper Truckee River has the highest average runoff (101,500 acre-ft) and Logan House Creek (330 acre-ft) the lowest. Instantaneous suspended-sediment and nutrient concentrations are highest during summer thunderstorms and rain-on-snow storms, but overall loads are greater during spring runoff.

Calculations for measured loads of suspended sediment and nutrients are shown for 10 tributary watersheds in figure 4 . As many as 368 analyses for a given variable are included. For each basin, "boxplots" are shown summarizing sampled loads for five selected constituents. For each constituent, the box shows the range in load for 25-75 percent of the samples. The median value (half the samples were less than this value and half were more) is indicated by the horizontal line through the box. The vertical lines above and below the box extend from the 10th percentile (only 10 percent of the samples were lower) to the 90th percentile (only 10 percent had higher values). For example, of the 307 suspended-sediment samples from the Incline Creek site, half (154) had loads between 0.11 ton per day (ton/d), the 25 th percentile, and 3.1 ton/d, the 75 th percentile. The range from 0.032 to 14 ton/d represented 80 percent of all samples (10th to 90th percentile). The median value was 0.61 ton/d.

The Upper Truckee River had the largest load of suspended sediment and all nutrients. This is because the Upper Truckee River Basin is the largest basin and contributes the most flow. The Logan House Creek Basin contributes the smallest sediment and nutrient loads. Watersheds on the western side of the basin (California) of the lake have higher loads of sediment and nutrients than the sites on the eastern side (Nevada) due to smaller drainage areas and less precipitation on the eastern side.

\section{Summary and Conclusions}

Lake Tahoe has long been admired for the clarity of its water and majestic mountain setting. Human activity in the basin has accelerated the decline in clarity and quality of this pristine lake. Resource-management agencies, such as TRPA, need long-term water-quality data to assess the effectiveness of both current and new projects and regulations. Since 1987, the LTIMP has been monitoring the water quality of surface-water and ground-water flow tributary to Lake Tahoe. Additional data are necessary to provide the basis for reliable quantification of nutrient loads to the lake from ground water. Additional scientific data and interpretation are essential for water managers to prioritize their efforts for the most effective protection of Lake Tahoe.

-Carol J. Boughton, Timothy G. Rowe, Kip K. Allander, and Armando R. Robledo

\section{Selected References}

Bauer, D.J., Foster, B.J., Joyner, J.D., and Swanson, R.A., 1996, Water resources data, Nevada, water year 1995: U.S. Geological Survey Water-Data Report NV-95-1, 734 p.

California Department of Water Resources, 1991, Truckee River atlas: Sacramento, Calif., $128 \mathrm{p}$.

California Regional Water Quality Control Board, 1995, Water quality control plan for the Lahontan Region (basin plan): South Lake Tahoe, Calif., 6 chapters, 5 appendixes.

Cartier, K.D., Peltz, L.A., and Long, Kati, 1995, Hydrologic basins and hydrologic-monitoring sites of Lake Tahoe Basin, California and Nevada: U.S. Geological Survey Open-File Report 95-316, 1 sheet.

Crippen, J.R., and Pavelka, B.R., 1970, The Lake Tahoe Basin, California-Nevada: U.S. Geological Survey Water-Supply Paper 1972, $56 \mathrm{p}$.

Farquhar, F.P., 1965, History of the Sierra Nevada: Berkeley, Calif., University of California Press, $262 \mathrm{p}$.

Goldman, C.R., 1988, Primary productivity, nutrients, and transparency during the early onset of eutrophication in ultra-oligotrophic Lake Tahoe, California-Nevada: Limnology and Oceanography, v. 33, no. 6, part 1, p. 1321-1333.

Goldman, C.R., and Byron, E.R., 1986, Changing water quality at Lake Tahoe-The first five years of the Lake Tahoe Interagency Monitoring Program, Tahoe: Tahoe Research Group, Institute of Ecology, University of California, Davis, $12 \mathrm{p}$.

Rush, F.E., 1973, Bathymetric reconnaissance of Lake Tahoe, Nevada and California: Nevada Division of Water Resources, Information Report 17,1 sheet.

Thodal, C.E., 1995, Hydrogeologic setting and ground-water quality of areas tributary to Lake Tahoe in Douglas County and Carson City, Nevada, through 1987: U.S Geological Survey Water-Resources Investigations Report 94-4079, 31 p.

Thodal, C.E, 1997, Hydrogeology of Lake Tahoe Basin, California and Nevada, and results of a ground-water quality monitoring network, water years 1990-92: U.S. Geological Survey Water-Resources Investigations Report 97-4072, 53 p.

-Publications support by Carol A. Myers and Angelia M. Thacker

\section{For more information please contact:}

Public Information Assistant

U.S. Geological Survey

333 W. Nye Lane, Rm 203

Carson City, NV 89706

tel.: (702) 887-7649

fax: (702) 887-7629

email: usgsinfo_nv@usgs.gov

URL: http://wwwnv.wr.usgs.gov 